\title{
Genetic Variability of Autochthonous Pear Varieties from Tuzla Canton, Bosnia and Herzegovina
}

\author{
Besim Salkić, Ensar Salkić, Amela Hercegovac, Aldijana Avdić, Azra Dorić, and Ahmed Salkić
}

\section{ABSTRACT}

Pear as a fruit species has a special place because of its quality characteristic. The fact that about $\mathbf{2 0 , 0 0 0}$ pear seedlings are considered to be sold annually in Bosnia and Herzegovina, which are autochthonous or spontaneously expanded varieties, also speaks in favor. The main goal of this research is to analyze the genetic variability of nine autochthonous pear varieties in Tuzla Canton, Bosnia and Herzegovina to enable the conservation and expansion of existing genetic resources. The study included nine autochthonous pear varieties. Samples of young leaves were collected on the following localities: the town of Srebrenik, the town of Gradačac, the municipality of Čelić-Tuzla Canton, Bosnia and Herzegovina, in the spring 2019. To determine genetic diversity, 12 SSR (Simple Sequence Repeats) markers were genotyped. There were no cases of synonyms or homonyms in the analyzed set. Each of the nine tested varieties represents a unique genotype. Autochthonous pear cultivars analyzed in this paper represent an interesting genetic resource, with useful agronomic traits that can be used in future cultivation.

Keywords: autochthonous varieties, pear, genetic diversity, SSR markers.

\author{
Published Online: October 31, 2021 \\ ISSN: 2684-5199 \\ DOI: 10.24018 / ejbio.2021.2.5.235 \\ Besim Salkić * \\ Associate professor, Department of \\ Agriculture, Faculty of Tehnology, \\ University of Tuzla, Bosnia and \\ Herzegovina. \\ (e-mail: besim.salkic @ untz.ba) \\ Ensar Salkić \\ Department of Agriculture, Faculty of \\ Tehnology, University of Tuzla, Bosnia \\ and Herzegovina. \\ (e-mail: ensar_bbm@windowslive.com) \\ Amela Hercegovac \\ Associate professor, Department of \\ Biology, Faculty of Science, University of \\ Tuzla, Bosnia and Herzegovina. \\ (e-mail: amela.hercegovac@untz.ba) \\ Aldijana Avdić \\ Assistant professor, Department of \\ Biology, Faculty of Science, University of \\ Tuzla, Bosnia and Herzegovina. \\ (e-mail: aldijana.tursunovic@untz.ba) \\ Azra Dorić \\ Department of Agriculture, Faculty of \\ Tehnology, University of Tuzla, Bosnia \\ and Herzegovina. \\ (e-mail: azradoric9@gmail.com) \\ Ahmed Salkić \\ Department of Agriculture, Faculty of \\ Tehnology, University of Tuzla, Bosnia \\ and Herzegovina. \\ (e-mail: salkic.ahmed94@hotmail.com) \\ *Corresponding Author
}

\section{INTRODUCTION}

The autochthonous gene pool of agricultural plants is invaluable from the point of genotypic structure and in given growing conditions can be a valuable source of genetic variability in selection and breeding.

Characterization of species germplasm is a topic of great interest to many countries that agreed to international standards under the FAO Agreement on Plant Genetic Resources. Genetic identification as well as physicochemical qualities of fruits of autochthonous pear varieties in Bosnia and Herzegovina represent a scientific research. The trend of planting fruit varieties which are resistant or tolerant to economically significant diseases, as well as customer demands for autochthonous varieties, has led nurseries in Bosnia and Herzegovina to graft and sell a pear assortment that is not on the Bosnian and Herzegovinas variety list. Grafted autochthonous varieties of pears are of local importance [1].

So, there is a problem of legatimacy of planting material production. The same statement can be applied to pear varieties that are traditionally grown in Bosnia and Herzegovina.

* This is because pears can grow in a wide range of climatic conditions as they are in Bosnia and Herzegovina. Different genotypes ripen from early summer to late autumn, pear fruits can be used in different ways, from fresh consumption to drying, making various processed products such as jams, juices, etc. [2]. Globally, agriculture is developing very fast, and traditional farming methods are being avoided, more and more people are going in the direction of intensive agricultural production based on 
modern technologies. The goal is maximizing income per area unit. Growing varieties that are highly productive and resistant to some economic diseases and pests leads to the uniformity of orchards, and thus also reduces genetic variability. Genetic variability is also defined as tendency of individual genotypes in a population to differ from each other. This term does not refer to the essence of the term 'genetic diversity' which means a rate of variation in a population [1]-[4].

Today, there are gene banks in the world that store plant genes, but their capacity is not large, so there are still a large number of plant genes that have not been collected and described.

The variability of a plant is determined by the environmental factors to which the plant adapts. Genetic variability is very important for biodiversity, which tends to adapt to the conditions in which the plant grows. Variability is an important factor which have an effect on individual response of plants to environmental stress and thus can lead to the differential survival of plants in a population under the influence of natural selection. Genetic variability also basically implies the differential susceptibility of organisms to disease and sensitivity.

In the Balkan Peninsula, where life has been accompanied by migrations and wars for centuries, fruit trees are synonymous for life for most people. Fruit trees are a sign that someone has settled in one place and wait for its growth and fruiting. Fruit trees are a sign that people will stay in that place for a long time. We can say that there is an almost cultic attitude towards fruit trees.

This type of attitude towards fruit trees has led to great genetic variability and the possibility of researching fruit trees, which is an extensive job, because they need to be located, identified, and collected.

Pear as a fruit species has a special place because of its quality characteristics. The fact that about 20,000 autochthonous or spontaneously expanded pear seedlings are sold annually in Bosnia and Herzegovina, supports this. The genus Pyrus probably originated in Central Asia, the mountainous parts of Western and Southern China, Asia Minor, and India, from where were expanded east and west of its primary center of origin [5]. Diversifications of the genus Pyrus, have been observed mainly in East and Central Asia, the Himalayas, the Caucasus, Asia Minor, and Eastern Europe. Maqsood cites research that determines how wild species of the genus Pyrus spread from the Balkans, Caucasus, Turkmenistan, Siberia to China, and Japan [6], while some species of the genus are naturalized in the United States, although this continent is not a natural habitat of the genus Pyrus [7]. According to Vavilov, they have three centers of origin of cultivated pears: the Chinese center, Central Asian and the Middle Eastern. In addition to these, Zeven and Zhukovsky proposed a fourth, Euro-Siberian center [8]. From the first organized expeditions, the pear was of interest to germplasm collectors. Most cultivars originate from P. communis L. [9], [10].

The genetic uniformity of commercial pear varieties in the United States and Europe is extremely high, so pear production is very vulnerable. About $50 \%$ of commercial pear production refers to the Williams variety (USDA, 2004). Additionally, there is a high genetic similarity between the varieties Williams and Conferance, probably because they originate from close genotypes and share the same genetic pool [11]. The diversity of cultivated plant species generally serves as the basis for biodiversity in agriculture [12]. It is very important to understand that by caring for biological diversity, we are actually caring for millions of lives, food, medicine, traditional and modern pharmacology [13]. Biological diversity is the variability of living organisms in all frameworks-including terrestrial, marine, and other aquatic ecosystems and the ecological complexes of which they are constituted, and this includes diversity within species, between species and diversity of ecosystems [14].

During the past decades, several researches of autochthonous fruit germplasm in Bosnia and Herzegovina have been done. In a review of the results of previous research conducted in the former Yugoslavia, Paunović et al. [19] provided information that this area has 124 registered wild fruit species and relatives. At the same time, research on wild fruits is very important [20], [21]. Paunović et al. [19] indicate that the area of $\mathrm{BiH}$ can be considered a gene center of some species and their wild relatives: Malus, Pyrus, Chaenomeles, Sorbus, Crataegus, Mespilus, Eriobotrya, Prunus, Amygdalus, Juglans, Corylus, Castanea, Cornus, Morus, Sambucus, Fragaria, Ribes, Rubus, Rosa, Ficus, Punica, Zizyphus, Citrus.

During the past decades, there have been several studies of autochthonous fruit germplasm in Bosnia and Herzegovina. In a review of the results of previous research conducted in the former Yugoslavia, Paunović and associates [19] provided data that this area has 124 registered wild fruit species. At the same time, the research of wild fruits is very important [20], [21]. Paunović et al. point out that the area of Bosnia and Herzegovina can be considered the gene center of some species and their wild relatives from the genera Malus, Pyrus, Chaenomeles, Sorbus, Crataegus, Mespilus, Eriobotrya, Prunus, Amygdalus, Juglans, Corylus, Castanea, Cornus, Morus, Sambucus, Fragaria, Ribes, Rubus, Rosa, Ficus, Punica, Zizyphus, Citrus. During the seventies of the last century, the area of the Balkans, and thus the former Yugoslavia / Bosnia and Herzegovina, was the subject of a large expedition [22], when a total of 225 varieties of pear were collected in Serbia, Kosovo, Bosnia and Herzegovina, Macedonia and Montenegro. Most of the varieties at the time of sampling were without signs of leaf disease or insect damage, including pear flea. The buds taken for propagation were sent to Glenn Dale (NPKQC-National Plant Germplasm Quarantine Center) where they were propagated on the Bartlet rootstock. The growth was vigorous. There was no effort to prevent infection either by spraying or pruning, unless there was a risk of plant loss. The plants were under observation from 1981-1988. The first big project to collect fruit germplasm, organized by former Yugoslavia researchers, was undertaken during the period 1988 and 1991 through the "Plant Gene Bank of Yugoslavia" project. The project included all activities: inventory, collection, identification, multiplication, characterization, and establishment of a gene bank. However, with the advent of the war years, this work was discontinued, and was resumed after 2000, through the SEED net project - Southeast European Development Network for Plant Genetic Resources [1]. 
There is more data in the available literature about germplasm characterization of autochthonous apple and pear cultivars [23]-[25] and genetic analysis of homonyms within the autochthonous apple gene pool in Bosnia and Herzegovina using SSR markers [26].

Characterization of germplasm involves activities to determine the expression of properties that are highly conditioned by a hereditary basis, ranging from analysis of morphological characteristics, through analysis of proteins to molecular markers. In Bosnia and Herzegovina, beside the inventory and collection of autochthonous germplasm [1], the characterization of autochthonous apple varieties [29] was also done.

Genetic diversity is essential for the effective management and use of genetic resources. Determination of genetic diversity is possible based on phenotypic/morphological traits or biochemical techniques based on analysis of enzymes, proteins or using DNA analysis based on molecular techniques, such as SSR marker analysis.

Molecular genetic methods are based on the analysis of the variability of hereditary material (DNA), which is very conservative. Hereditary material is transmitted from generation to generation within normal growing conditions through vegetative propagation, as a rule, without the influence of environmental factors. In other words, the content and structure of hereditary material (genomic and cytoplasmic DNA) of new plants during vegetative reproduction usually remain the same - unchanged. Therefore, methods based on the analysis of DNA structure are very suitable for identification purposes, because once determined the characteristics of DNA by the same method in one place can be checked by the same method in any other place and at any stage of plant development. Variation of weather conditions, soil type or altitude can have a significant impact on the phenotype characteristics of variety, while the genetic profile determined by molecular genetic analysis even under changed conditions will remain unchanged. If the established genetic profile of a variety differs from the profile of other varieties, then its stable repeatability can be successfully used for identifying of varieties, which is crucial in the characterization of germplasm in fruit growing and viticulture [30]. The main goal of this research is to analyze genetic variability of nine autochtonous pear varieties in Tuzla Canton, Bosnia and Herzegovina in order to preserve and expand existing genetic resources through registered nurseries.

\section{MATERIAL AND METHODS}

\section{A. Sampling}

The research included nine autochthonous pear varieties from Bosnia and Herzegovina, as follows: Mesnjača, Žutica, Ječmenka, Pšeničnjača, Savka, Okrugla, Karamanka, Huremka i Kongreska 22. Samples of young leaves were collected on the following localities: the town of Srebrenik, the town of Gradačac, the municipality of Čelić-Tuzla Canton, Bosnia and Herzegovina, in the spring 2019.

For each examined variety, 10 healthy, undamaged leaves were taken. The plant material was dried in a digester with a homogeneous air flow for 10 days, in genetic laboratory, Department of Biology, Faculty of Science, University of Tuzla. The samples were then transported in paper bags with silica beads to the INGEB Institute of Genetic Engineering and Biotechnology, Sarajevo, for further molecular genetic analysis.

\section{B. Isolation of Genomic DNA from Young Pear Leaves}

After fragmentation of the plant tissue, genomic DNA isolation was performed with Soltis Lab CTAB DNA kit according to the manufacturer's protocol. In the first isolation step, the samples were incubated in lysis buffer overnight Then after adding 24:1 chloroform:Isoamyl alcohol the samples were centrifuged. The upper phase of the supernatant was transferred to a new tube, and after the addition of $7.5 \mathrm{M}$ ammonium acetate and isopropanol placed on ice and centrifuged again. The precipitate was washed with $70 \%$ and absolute ethanol, followed by drying of the DNA precipitate at the bottom of the tube. DNA was dissolved in $\mathrm{ddH} 2 \mathrm{O}$ and used for amplification.

\section{SSR Analysis}

For DNA amplification, the KAPA3G Plant PCR kit (Kapa Biosystems) was used according to the appropriate manufacturer's protocol. Polymerase chain reaction (PCR) amplification of microsatellite sequences took place in the GeneAmp PCR System 9700 (Applied Biosystems, United States). To confirm the authenticity of varieties and determine the genetic diversity, twelve microsatellite markers used in studies on peach genotyping were used: $\mathrm{CH} 02 \mathrm{~b} 10, \mathrm{CH} 03 \mathrm{~g} 07$, EMPC117, CH05e03, CH02CO2a, EMPC11, CH03D12, $\mathrm{CH} 02 \mathrm{C} 11, \mathrm{CH} 01 \mathrm{~d} 03, \mathrm{CH} 04 \mathrm{e} 03, \mathrm{CH} 01 \mathrm{~d} 09$ and $\mathrm{CH} 01 \mathrm{f07a}$ The names and sequences of the primers, as well as the conditions for carrying out PCR are described earlier $(28,29,30)$ Detection of DNA profiles and fragment sizes was performed using fluorescently labeled primers with the internal standard GeneScan-500 LIZ, and PCR products were analyzed on an ABI PRISM (B3500 automatic sequencer (Genetic Analyzer 3500, Applied Biosystems) with 8 capillaries $50 \mathrm{~cm}$ long, which enables separation and analysis of DNA fragments according to the principle of capillary electrophoresis and as detection by CCD camera. All electrophoresis data were collected in the ABI PRISM $®$ Collection software.

\section{Biostatistical Analysis}

Biostatic analysis involved calculating the number of detected alleles (DA) and expected (EH) heterozygosity [31] in computer program SPAGeDI 1.3, [32]. The effective allele number (AE) was calculated in the computer program GenAlEx [33], UPGMA cluster analysis based on the Jaccard similarity coefficient was used to determine similarities between genotypes and was performed in the computer program MEGA 6 (Molecular Evolutionary Genetics Analysis) [34].

\section{RESULTS AND DISCUSSION}

In all analyzed microsatellite locus, amplification was successful. In general, the size of the amplified DNA fragments scored ranged from 95 to $254 \mathrm{bp}$, are described earlier [28]-[30]. Detection of DNA profiles and fragment 
sizes was performed using fluorescently labeled primers with the internal standard GeneScan-500 LIZ, and PCR products were analyzed on an ABI PRISM $₫ 3500$ automatic sequencer (Genetic Analyzer 3500, Applied Biosystems) with 8 capillaries $50 \mathrm{~cm}$ long, which enables separation and analysis of DNA fragments according to the principle of capillary electrophoresis and as detection by CCD camera. All electrophoresis data were collected in the ABI PRISM ${ }^{\circledR}$ Collection software. UPGMA cluster analysis based on the Jaccard similarity coefficient was used to determine similarities between genotypes and was performed in the computer program MEGA 6 (Molecular Evolutionary
Genetics Analysis) [34]. Genetic profiles of nine tested pear samples, based on 12 analyzed microsatellite locus are showen in Table I. Effective number of alleles (EA), number of detected alleles per locus (DA), ratio between effective and detected number of alleles per locus (EA/DA) and expected (EH) heterozygosity for 12 SSR locus are also shown in Table II. Among the investigated samples, the mean values of detected alleles (DA) and effective alleles (EA) were 6.30 and 4.70 , respectively. The expected heterozygosity $(\mathrm{EH})$ was within $0.67-0.92$.

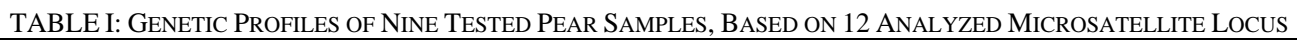

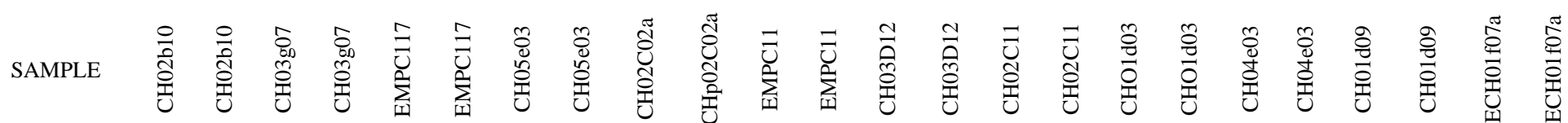

\begin{tabular}{|c|c|c|c|c|c|c|c|c|c|c|c|c|c|c|c|c|c|c|c|c|c|c|c|c|}
\hline Okrugla & 112 & 155 & 200 & 240 & 95 & 119 & 178 & 178 & 128 & 142 & 134 & 134 & 107 & 111 & 222 & 222 & 135 & 150 & 175 & 194 & 127 & 145 & 183 & 197 \\
\hline Karamanka & 140 & 155 & 230 & 240 & 95 & 115 & 174 & 174 & 130 & 130 & 148 & 148 & 107 & 123 & 213 & 239 & 135 & 150 & 178 & 185 & 154 & 154 & 190 & 190 \\
\hline Ječmenka & 140 & 155 & 230 & 242 & 113 & 135 & 162 & 162 & 128 & 134 & 136 & 136 & 107 & 119 & 235 & 235 & 133 & 150 & 175 & 178 & 129 & 143 & 190 & 190 \\
\hline Huremka & 155 & 155 & 242 & 242 & 113 & 115 & 172 & 172 & 128 & 128 & 148 & 148 & 119 & 125 & 217 & 237 & 153 & 153 & 178 & 197 & 131 & 164 & 180 & 190 \\
\hline Savka & 155 & 155 & 240 & 240 & 119 & 119 & 188 & 188 & 128 & 128 & 136 & 136 & 107 & 119 & 222 & 235 & 133 & 153 & 173 & 178 & 127 & 145 & 192 & 190 \\
\hline Pšeničnjača & 110 & 155 & 200 & 240 & 117 & 123 & 188 & 188 & 128 & 128 & 140 & 144 & 107 & 111 & 222 & 235 & 133 & 153 & 173 & 194 & 133 & 145 & 183 & 190 \\
\hline $\begin{array}{l}\text { Kongreska } \\
22\end{array}$ & 110 & 128 & 224 & 254 & 107 & 111 & 164 & 164 & 130 & 144 & 144 & 144 & 107 & 125 & 213 & 237 & 135 & 153 & 185 & 190 & 137 & 155 & 180 & 18 \\
\hline Žutica & 112 & 155 & 200 & 242 & 113 & 119 & 188 & 188 & 128 & 134 & 144 & 144 & 107 & 111 & 222 & 222 & 133 & 150 & 173 & 173 & 127 & 145 & 183 & 195 \\
\hline Mesnjača & 128 & 140 & 224 & 230 & 111 & 111 & 164 & 164 & 128 & 144 & 148 & 148 & 109 & 125 & 215 & 237 & 133 & 153 & 178 & 185 & 133 & 155 & 183 & 190 \\
\hline
\end{tabular}

TABLE II: RANGE OF DETECTED ALLELES, NuMBER OF DETECTED ALLELES (DA), EFFECTIVE NUMBER OF ALLELES (EA), RATIO (RATIO) BETWEEN EFFECTIVE AND DETECTED NUMBER OF ALLELES (EA / DA), EXPECTED (EH) HETEROZYGOSITY FOR 12 SSR LOCUS ON NINE TESTED

\begin{tabular}{cccccc}
\multicolumn{7}{c}{ SAMPLES PEARS } \\
\hline Locus & Range & DA & EA & EA/DA & EH \\
\hline CH02b10 & $110 / 155$ & 5,0 & 3,2 & 0,64 & 0,73 \\
CH03g07 & $200 / 254$ & 6,0 & 5,1 & 0,85 & 0,85 \\
EMPC117 & $95 / 135$ & 9,0 & 7,0 & 0,78 & 0,91 \\
CH05e03 & $162 / 188$ & 6,0 & 4,8 & 0,80 & 0,84 \\
CH02C02a & $128 / 144$ & 5,0 & 2,7 & 0,54 & 0,67 \\
EMPC11 & $134 / 148$ & 5,0 & 4,0 & 0,80 & 0,79 \\
CH03D12 & $107 / 125$ & 6,0 & 4,2 & 0,70 & 0,80 \\
CH02C11 & $213 / 239$ & 7,0 & 4,8 & 0,69 & 0,84 \\
CH01d03 & $133 / 153$ & 4,0 & 3,8 & 0,95 & 0,78 \\
CH04e03 & $173 / 197$ & 7,0 & 5,4 & 0,77 & 0,86 \\
CH01d09 & $127 / 164$ & 10,0 & 7,7 & 0,77 & 0,92 \\
CH01f07a & $180 / 197$ & 6,0 & 3,4 & 0,57 & 0,75 \\
Average & & 6,3 & 4,7 & 0,75 & 0,81 \\
\hline
\end{tabular}

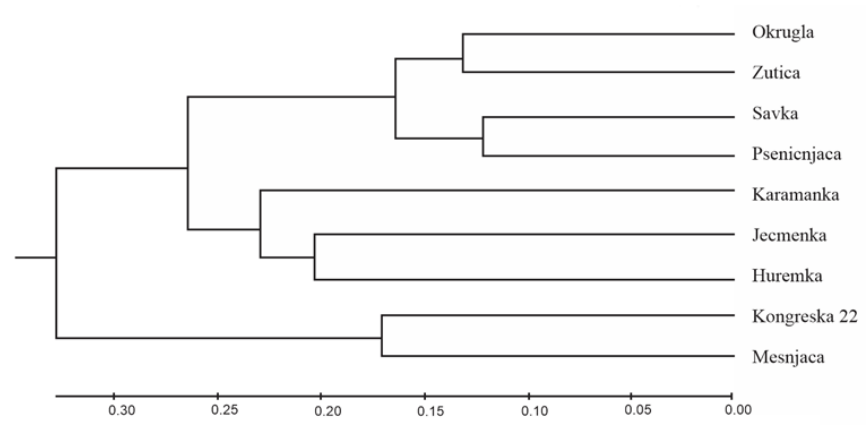

Fig. 1. UPGMA cluster analysis based on Jaccard's similarity coefficient, performed based on polymorphism of 10 SSR locus within nine apple samples.

The obtained dendogram indicates a pronounced differentiation, i.e., each of the nine examined varieties represents a unique genotype. Assessment of genetic diversity within a cultivated crop has important consequences in breeding and the conservation of genetic resources.

\section{CONCLUSION}

The results of the research enabled the identification of 9 analyzed autochthonous pear varieties from the Tuzla Canton in Bosnia and Herzegovina: Mesnjača, Žutica, Ječmenka, Pšeničnjača, Savka, Okrugla, Karamanka, Huremka and Kongreska 22 as unique genotypes. Among the nine samples examined, there were no cases of synonyms or homonyms. The examined sets of genotypes possess significant genetic variability, which is especially important because relatively small number of samples were analyzed. The autochthonous pear varieties analyzed in this paper represent an interesting genetic resource, with useful agronomic traits that can be used in future cultivation. Such results certainly impose the importance of their adequate preservation.

\section{COMPETING INTERESTS}

All the authors declare that they have no conflict of interest.

\section{REFERENCES}

[1] G. Đurić, L. Tomić, N. Mićić, M. Cvetković, L. Radoš, B. Pašalić, "Fruit genetic resources in Republica Srpka", Acta Agriculturae Serbica vol. 14 (28), pp. 31-40, 2009.

[2] M. Mićić, G. Đurić, B. Salkić, "Pomological charecterisation of pear varieties of "Lubeničarka" group," Agro knowledge Jurnal, 1, pp:1530. UDK: 634.13-152.6 (497.6), 2012.

[3] K. Kanlić, Autohtone sorte voćaka istočne Bosne, Fojnica d.d.ISBN: 978-9958-585-86-9: Štamparija Fojnica, January 2010.

[4] V. Beširević, Autohtone jabuke $i$ kruške sa prostora Bosne $i$ Hercegovine, Tuzla, Harfo-graf, 2009.

[5] J. S. Douglas, R. A. de J. Hart, "Forest farming: Towards a solution to problems of world hunger and conservation," 1976, London: Watkins. 
[6] N. I. Vavilov, "Origin, Variation, Immunity, and Breeding of Cultivated Plants," Selected Writings, Rusia, 1951.

[7] A. Rehder, "Manual of cultivated trees and shrubs hardy in North America, second edition", Dioscorides Press, Portland, 1986.

[8] A. Maqsood, "Biodiversity in pears (pyrus spp.): Characterization and conservation of germplazm from Azad Jammu and Kashmir," Doctoral thesis. Department of Horticulture University College of Agriculture Bahauddin Zakariya University Multan, 2008, p. 265.

[9] A. Stančević, "Kruška," Nolit, Beograd, 1980, p. 298.

[10] R. Gliha, "Sorte krušaka u suvremenoj proizvodnji," Fragaria, Zagreb, 1997 , p. 278

[11] A. Wunsch and J.I. Hormaza, "Characterisation of variabilkity and genetic similarity of European pear using microsatellite developed in apple," Scietia Horticulturae, 2007, vol. 173, pp. 37-43.

[12] M. Penčić, „Biljni genetički resursi: izabrani radovi,” Jugoslovenska inženjerska akademija, (2005), Beograd.

[13] Nordic Council of Ministers, Access and Rights to Genetics Resources: A Nordic Approach, 2003, Copenhagen, Danmark.

[14] L. Glowka, "An introduction to the Convention on Biological Diversity, page 15-19", IUCN/IAE, 1994, Gland, Switzerland.

[15] Š. Bubić, "Specijalno voćarstvo," 1977, Svjetlost, Sarajevo, str: 383.

[16] M. Milovankić, "Pomologija I i II - skripta poljoprivrednog fakulteta u Novom Sadu," 1963, Novi Sad.

[17] Dž. Jarebica, M. Kurtović, "Oplemenjivanje voćaka i vinove loze“ opšti dio, 1997, "EDIS", Sarajevo.

[18] H. Krümmel, "The World Almanac and book of facts," 1961, Norwark, Oakland.

[19] S. A. Paunović, A. S. Paunović, N. Mićić, "Gene centers of wild fruit tree species and their relatives in SFR Yugoslavia", International Horticultural Scietific Conference "Biological and Tehnical Development in Horticulture," Lednice na Morave, September 9th12th, 1997. Appendix II, 6-12.

[20] N. Mićić, M. Kurtović, G. Đurić, N. Štrbac, “Ocjena uspješnosti gajenja džonagolda, zlatnog delišesa i ajdareda u zajedničkoj sortnoj kompoziciji," Poljoprivredni pregled, broj 4, 5, 6. Str:59-68, 1987.

[21] R. Miletić, M. Mitrović, G. Đurić, N. Mićić, "Biological Potential of European Filbert (Corylus avellana L.) growing wild in Eastern Serbia," Acta Horticulturae, vol. 445, pp. 223-228, 1997.

[22] T. Zwet, D. Stanković, B. Ristevski, "Collecting Pyrus Germplasm in Yugoslavia," HortScience, 22: pp. 15-21,1987.

[23] S. Marić, R. Bošković, M. Lukić „The polymorphism of ETR1 gene in autochthonous apple cultivars. Genetika, Vol. 39, No. 3, pp. 387-394, 2007.

[24] F. Martinelli, B. Mateo, C. Fabiano, F. Corrado, S. Agostino, S. Luca, "Ancient Pomoideae (Malus domestica Borkh and Pyrus communis L.) cultivars in "Apenino Toscano" (Tuscany Italy): molecular (SSR) and morphological characterization 2008," Caryologia, Vol. 61, no. 3, pp. 320-331

[25] G. Ianni, P. Mariotti, "Conservation and exploitation of woody plant genetic resources at the CNR/IVALSA Institute of Florence,". The role of biotechnology, Villa Gualino, turin, Italy, 2005.

[26] F. Gaši, S. Šimon, N. Pojskić, B. Salkić, F. Hadžimurtezić, M. Kurtović, I. Pejić, "Genetic analysis of homonyms within an autochthonous apple genofund in Bosnia and Herzegovina using SSR markers," Works of the Agricultural and Food Faculty of the University of Sarajevo, God. LV, No. 60/1: 83-95. UDC 63/66 (058), 2010.

[27] F. Fernandez-Fernandez, N.G. Harvey, C.M. James, "Isolation and characterization of polymorphic microsatellite markers from European pear (Pyrus Communis L.)," Mol. Ecol. Notes 6, pp. 1039-1041, 2006.

[28] F. Gasi, M. Kurtovic, B. Kalamujic, N. Pojskic, J. Grahic, C. Kaiser, et al., "Assessment of European pear (Pyrus communis L.) genetic resources in Bosnia and Herzegovina using microsatellite markers," Sci Hortic. Vol. 157, pp. 74-83, 2013.

[29] I. Pejić i sar., "Metode oplemenjivanja višegodišnjih kultura i biotehnologija u oplemenjivanju bilja-interna skripta. Modul: AG-1075 Oplemenjivanje bilja (prof. dr. V Kozumplik, koordinator, Agronomski fakultet, Zagreb.or population levels," Molecular Ecology Notes 2, 2002, pp. 618-620, 2007.

[30] A. Skender, M. Kurtović, S. Hadžibulić, F. Gaši, A. Maličević (2008): "Morfološke i hemijske karakteristike ploda autohtonih genotipova kruške Centralne Bosne," Radovi Poljoprivrednog fakulteta Univerziteta u Sarajevu.

[31] M. Nei, "Estimation of average heterozigosity and genetic distance from a small number of individuals," Genetics, Vol. 89, pp. 3583-3590, 1978.

[32] O. J. Hardy, X. Vekemans (2002). SPAGeTI: a versatile computer program to analyse spatial genetic structure at the individual or population levels. Molecular Ecology Notes 2, pp. 618-620.

[33] R. Peakall, P. E. Smouse GenAlEx 6.5: Genetic analysis in Excel. Population genetic software for teaching and research- an update, 2012.
[34] K. Tamura, G. Stecher, D. Peterson, A. Filipski, S. Kumar, "MEGA6: Molecular Evolutionary Genetics Analysis Version 6.0," Mol Biol Evol 30: $2725-2729,2013$. 